\title{
Development Of Mathematics Teaching Materials Oriented Mathematic Literation And Life Enterpreneurship
}

\author{
Alpha Galih Adirakasiwi ${ }^{\text {a }}$, Attin Warmi ${ }^{a}$, Achmad Nawawi ${ }^{\text {b }}$ \\ Corresponding authors: alpha.galih@fkip.unsika.ac.id \\ ${ }^{a}$ Mathematics Education Departement, Universitas Singaperbangsa Karawang, Karawang , Indonesia \\ ${ }^{a}$ Economics Departement, Universitas Singaperbangsa Karawang, Karawang , Indonesia
}

Keywords: Teaching materials, Mathematical literacy, Entrepreneurial Spirit

\begin{abstract}
Mathematical literacy is a very hot issue in the development of mathematics learning, apart from mathematical literacy, another interesting thing is the entrepreneurial spirit that must be given from an early age, especially for vocational students. This research was conducted at SMK Rosma Karawang in the Department of Computer and Network Engineering, West Java Province with the XI grade students. The teaching materials developed by applying the principles of the development model developed with the ADDIE model consist of analysis, design, development, implementation and evaluation. This research and development model is considered suitable for developing teaching tools and materials which is used for the purposes of the learning process. Based on the results of data analysis and processing that have been carried out in this study, the development of teaching materials using the ADDIE model has met the appropriate and valid criteria by media, language and media expert valuators. Another result of developing this teaching material besides meeting the eligibility criteria is that the teaching materials developed are able to increase mathematical literacy and instill entrepreneurial spirit for students.
\end{abstract}

\section{Introduction}

Mathematical literacy has become a hot issue that has developed in recent years (Letwinsky, 2017; Mariani et al., 2017). This was initiated by PISA (Program for International Student Assessment) which released the literacy results of students in the world aged 15 years. PISA informed the results in its release, including the results of mathematical literacy in Indonesia, which were still below other ASEAN countries, even Singapore became an ASEAN country in the top 10 results released by PISA (Amir et al., 2019; Ekawati et al., 2020; Hayati \& Kamid, 2019). Therefore mathematical literacy is an interesting issue and the government is trying to increase the mathematical literacy score of students in Indonesia. Mathematical literacy can simply be defined as the ability or capacity of individuals to formulate and use mathematics in various ways (ILHAN \& ASLANER, 2017; Kelana et al., 2020; Kitsantas et al., 2020). This statement states that in mathematical literacy students are expected to be able to use reasoning to help students solve problems related to everyday life (Asmara et al., 2017; Leonard et al., 2020; Yüca, 2017) .This provides benefits to the students to understand the usefulness of mathematics in everyday life har i (Ic \& Tutak, 2018; Purpura et al., 2017) .

The definition of mathematical literacy does not only focus on mastering the concept of material, but more than that mathematical literacy is needed in developing critical and creative thinking skills and reasoning in solving mathematical problems. (Sumirattana et al., 
2017) Before the release of PISA regarding mathematical literacy, NCTM (1989) has released limitations regarding mathematical literacy which are contained in 4 main components, namely students' ability to explore, connect and do logical reasoning and use various mathematical methods. . The 4 components are important components that students have in solving problems (Kastberg et al., 2016). We agree that students who have mathematical literacy skills are not only able to understand mathematics but more than that students are able to solve daily problems that are often faced by students.

PISA provides a framework for developing mathematical literacy skills (Diputra et al., 2019). These three things consist of mathematical content or content, students' responses to the symptoms being observed, and then the third is how the responses are related to mathematics. Process components are very important in building mathematical literacy, the process components themselves consist of components of the reproduction process, components of the connection process and components of the reflection process. All three are important and must be turned on in the mathematics learning process, especially at the connection stage where students must be able to connect several ideas in solving math problems. Connection also means that students must be able to understand the material with each other in answering math problems, which generally means that in answering one question, several materials are needed to answer it.

Mathematical literacy is an important ability in the abilities of the 21 st century (Fajriyah et al., 2019). This is because mathematical literacy rests on students' ability to do logical reasoning in solving problems (Kang \& Cogan, 2020; Pradana et al., 2020). Using logical reasoning means that these students are able to choose the right strategy in solving a problem. Therefore, this ability becomes a point in developing students' abilities in the 21 st century as a provision for solving problems in everyday life (Gabriel et al., 2020; Ülger et al., 2020).

In addition to mathematical literacy skills that need to be developed, students also need to be equipped with an entrepreneurial spirit. A simple definition of entrepreneurship is not limited to trading, but more than that the entrepreneurial spirit possessed by a person must be able to add value to a product (Frederiksen, 2017; Hägg \& Kurczewska, 2019; Kamid et al., 2020). A person, who makes the idea ofused drinks into a pencil holder, has actually applied the principles of an entrepreneurial spirit. In addition, someone who has a good entrepreneurial spirit can see what opportunities can be used so that something will increase in value both in quality which can be viewed from the economy. The entrepreneurial spirit is important until the entrepreneurship course becomes a compulsory subject in higher education in order to provide students with the tighter competition in the world of work (Hasan et al., 2019; Nurhidayati et al., Nd; Obrecht, 2016; Yuliati et al., 2016). Entrepreneurship can also be interpreted as the attitude of someone who has strong independence with high innovation. Good innovation can be interpreted as thinking that is original and different from the others. Original thinking can only be done if you have good literacy skills, because these two things are closely related (Nurjamiah et al., Nd; Rahmi, 2017).

Students of Vocational Schools (SMK) are very close and close to the business world. Even the orientation of vocational students is orientation towards the business world and also creates business fields. Efforts need to be made so that the mindset of students leaving vocational high schools from looking for work to create jobs. Through this research, how vocational students learn mathematics can be improved their mathematical literacy skills and entrepreneurial spirit. This is based on these two things which are a necessity that must be possessed by students in facing their future which is faced with very fierce competition. Efforts that can be made by teachers, especially vocational teachers, are to make teaching materials oriented towards literacy skills and entrepreneurial spirit. 
Teaching materials can simply be interpreted as a systematic set of materials that have been prepared by educators for their students (Pujiastuti et al., 2020; Rusdi et al., 2019). Teaching materials are used as a means for students to be able to learn independently after studying in class with the teacher. Teaching materials can be made by looking at the competencies expected by the teacher so that the making of teaching materials can be directed at the competencies to be achieved. The development of instructional materials with an entrepreneurial orientation combines the concept of learning mathematics with problems in everyday life with an entrepreneurial spirit. Entrepreneurial oriented mathematics teaching materials need to be given to vocational students because vocational students have an orientation towards the business world and the attitude of an entrepreneurial attitude must be given since learning in school is no exception during the mathematics learning process.

\section{Methods}

This research was conducted at SMK Rosma Karawang in the Department of Computer and Network Engineering, West Java Province with 28 students of class XI. Teaching materials are developed by applying the principles of the development model developed with the ADDIE model, which consists of analysis, design, development, implementation and evaluation (Ghani et al., 2018; Gusmida et al., 2017). This research and development model is considered suitable for developing teaching tools and materials used for the purposes of the learning process.

The development of teaching materials oriented to mathematical literacy and an entrepreneurial spirit is carried out in the following stages: The first stage of analysis, this stage has been carried out by researchers as a result of initial observations in the mathematics learning process at SMK Rosma Karawang even though it is carried out through zoom meetings. The analysis carried out was that student' needs in understanding mathematics material as an integral part of mathematical literacy, the second need is the development of entrepreneurial oriented teaching materials so that vocational students are equipped with an entrepreneurial spirit through mathematics learning carried out by the teacher. The second stage is design; design is a key activity in the development of teaching materials oriented to mathematical literacy and entrepreneurship. Determining the structure of the material and compiling the assessment instrument by the validated is carried out at this stage. The third stage is development, at this stage the development of teaching materials and also validating the experts. The validation of this teaching material was carried out on three experts, namely linguists, media experts and mathematicians. These three experts were given instruments to be able to assess the appropriateness of the teaching materials created and developed by the research team. The fourth stage is implementation; this stage is to try out the teaching materials that have been made for students at SMK Rosma Karawang. The last stage is the evaluation at this stage an assessment of the feasibility of teaching materials both in terms of language, appearance and content in the teaching materials, besides that, an effectiveness test is also carried out on students at SMK Rosma Karawang.

\section{Results}

This research uses a development research type using the ADDIE development model consisting of: analysis, design, development, implementation and evaluation. Before developing teaching materials, the problems and needs needed by vocational students are first carried out. Observations were made when vocational teachers were teaching in class even though they were through zoom meetings due to a pandemic situation. Some things that can be analyzed after observing learning in the class are as follows: 1) the lack of student motivation and boredom for students because it has been long enough to carry out learning 
with an online system not face to face, therefore it is necessary to innovate so that learning online can still be done effectively and able to increase student motivation in its implementation, 2) lack of learning resources owned by students, in other words students only rely on material from the teacher in the learning process so that the discussions that are carried out are not too running because of the tendency of vocational students who are passive especially in their eyes exact lessons. 3) The learning resources used by teachers are not systematically designed and only refer to teacher books and student books issued by the government through the ministry of education and culture, so it seems that the sources are not varied enough. Based on this analysis, it can be seen that it is necessary to develop teaching materials that refer to mathematical literacy and an entrepreneurial spirit as capital for vocational graduates who are projected to be ready to face the business world and the industrial world. Through mathematical literacy oriented development, students build their abilities through their context in everyday life. This is based on the characteristic of mathematical literacy is the existence of problems that arise in the context according to the students who are the target in the learning process. Through learning that is oriented towards an entrepreneurial spirit, the mathematics teacher who teaches these Vocational School students has been given an understanding and cultivation of entrepreneurial spirit and nature which is an asset for students to be able to develop their competence so that they are able to compete with other people with world conditions that are faced with competition between humans and humans and between humans and technology.

The second stage in the process of developing teaching materials carried out by the teacher is the design stage. This is an important stage so that the teaching materials made meet the eligibility criteria made. Several things that underlie the making of teaching materials are that teaching materials must be equipped with daily problems and also teaching materials need to be made in order to improve entrepreneurial attitudes and mathematical literacy. Some of the results made by teaching materials on linear program material are as follows:

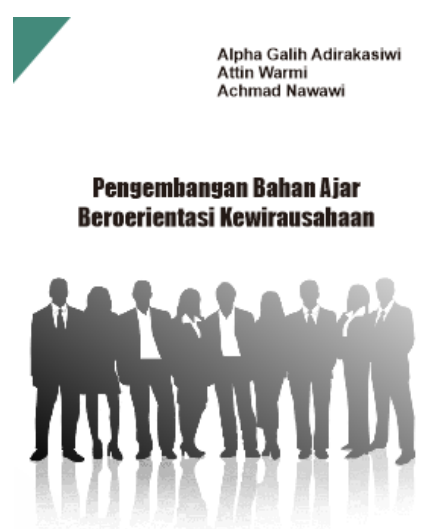

\section{Figure 1 Cover of Teaching Materials}

The cover design of teaching materials is adjusted to the main focus of this study, which is entrepreneurial-based teaching materials, so that the cover is made with a background image of people who are characteristic of the entrepreneurial spirit. In addition to the title of the teaching material, the author is also included so that it provides an overview of this research, then after the cover design of the teaching material is an introduction, as follows: 
KATA PENGANTAR

Puja dan puji kami haturkan kepada Tuhan YME, Allah SWT yang telah memberikan rahmat dan karunianya sehingga dalam setiap aktivitas kita diberikan kelancaran oleh-Nya. Buku Bahan ajar ini tak lain sebagai salah satu bahan pelengkap dari kurikulum 2013 yang dapat mempermudah peserta didik dalam proses pembelajaran pada materi program linier.

Bahan ajar ini merupakan suplemen atau tambahan dalam memahami materi matematika. Salah satu materi yang disajikan dalam buku ini adalah program linier. Program linier merupakan materi yang kaitannya dengan dunia nyata dan beroerientais pada jiwa entrepreneur. Seseorang yang akan menjadi wirausaha tentu harus memahami variabel variabel ketika dalam melaksanakan usahanya, materi program linier sangat cocok untuk memberikan kemanfaatan bagi siswa dalam pemahaman dan pelatihan siswa tentang wirausaho.

Akhirnya, dengan segala kerendahan hati, penulis senantiasa mengharapkan kritikan dan saran yang membangun dari berbagai pihak. Semoga hal yang penulis perbuat dapat menjadi sumbangan bagi kemajuan pendidikan di Indonesia, semoga bermanfaat bagi para pembaca, dansemoga bernilai ibadah disisi- Nya. Aamiin. Billah fii Sabilil Haq Fastabiqul Khaerat

Karawang. September 2020

Penulis

Figure 2 Display foreword

Foreword at the beginning of a teaching material, the foreword in this material is made with an introductory part, then in the second paragraph an introduction is also given to the material in teaching materials, namely the linear program. Linear program is material that has a lot to do with business activities so that this teaching material is very suitable if it is connected with an entrepreneurial spirit, the third part of this teaching material contains instructions, instructions are made to make it easier for students to understand teaching materials and use teaching materials systematically. An overview of the instructions for teaching materials is as follows:

3. Uraian materi merupakan materi pokok dalam bahan ajar, disajikan dengan menggunakan bahasa yang mudah dipahami serta pengisian titik - titik untuk melengkapi kalimat yang menjadi point penting untuk diketahui siswa tentang Program Linier.

Bahan ajar matematika pada materi Program Linier yang disusun untuk membantu peserta didik kelas XI SMA dalam meningkatkan kemampuan pemahaman matematik dan keterampilan dalam berwirausaha. Peryusunan bahan ajar ini disesuaikan dengan kompetensi inti dan kompetensi dasar pada kurikulum 2013 revisi. Bahan ajar ini diharapkan dapat menjadi suatu acuan referensi bagi guru maupun calon guru dalam membimbing peserta didik mempelajari materi Program Linier. Hal ini dikarenakan materi Program linier baryak digunakan dalam menyelesaikan mosalah - mosalah optimasi dalam bidang industri, perbankan, pendidikan, serto masalah lainnya yang dapat dinyatakan dalam bentuk linier. Sehingga sangat penting bagi siswa untuk memahami sekaligus menerapkan materi Program Linier dalam berbogai aspek kehidupan.

1. Sebelum ke pembahasan, bahan ajar ini diawali dengan pemaparan kompetensi yang harus dicapai peserta didik.

2. Poda awal materi bahan ajar, diberi permasalahan matematis yang berkaitan dengan materi Program Linier.

3. Uraian materi merupakan materi pokok dalam bahan ajar, disajikan dengan menggunakan bahasa yang mudah dipahami serta pengisian titik - titik untuk melengkapi kalimat yang menjodi point penting untuk diketahui siswa tentang Program Linier.

4. Diberikan permasalahan matematis pada materi Program Linier yang disertai dengan adarya pengarahan dalam mengerjakan permasalahanrya.

5. Latihan berupa soal - soal untuk menguji kemampuan peserta didik dalam memecahkan masalah matematis pada materi Program Linier.

Berikut langkah - langkah bogi peserta didik dalam menggunakan bahan ajar ini:

1. Membaca doa sesuai dengan keyakinan masing - masing agar diberi kemudahan dalam mempelajari materi bahan ajar.

2. Membaca kompetensi yang harus dicapai oleh peserta didik terlebih dahulu.

3. Gunakan buku paket Matematika kelas XI dan media belajar lainnya sebogai bahan referensi peserta didik.

4. Mengamati suatu masalah beserta arahan dalam meryelesaikan permasalahan yang telah disediakan.

5. Pahamilah setiap arahan pada permasalahan yang diberikan, baik yang disajikan pada materi maupun pada masalah yang disajikan.

6. Pelajari dan pahami logi materi bahan ajar sebelum mengerjakan soal evaluasi

Instructions are made as reference materials so that students can understand the use of this teaching material. The instructions also show brief and systematic steps in understanding this teaching material. Regarding the teaching materials made in the instructions, problems are also given at the beginning of learning so that students understand problems that are related to economic activity, this is so that students understand the real world in the context of problems 
related to economic activity, then after the instructions are also made core competencies and basic competencies that must be achieved in the mathematics learning process.

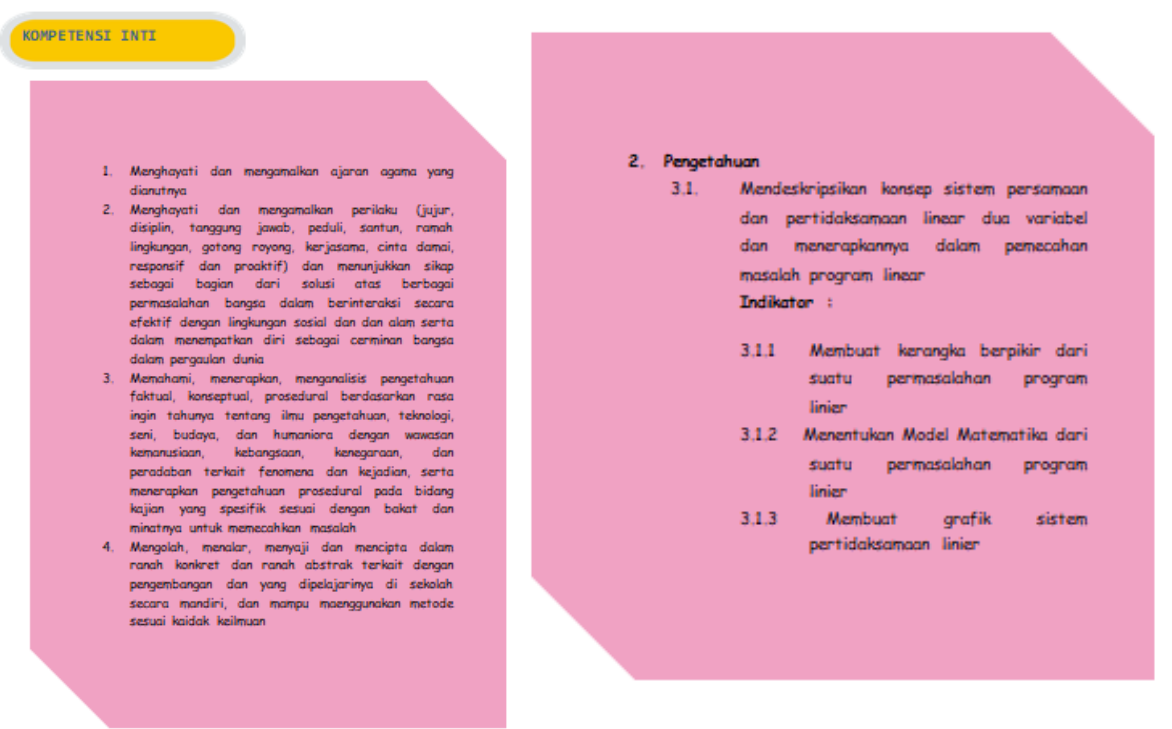

Figure 4 Core Competencies and Basic Competencies

Core competencies and basic competencies are made to make it easier for students to understand what abilities they should have after understanding the material contained in this teaching material. Core competencies are an outline, while core competencies are competencies that refer to the material being studied; basic competencies are then lowered to indicators of competency achievement up to learning objectives. Learning objectives are competencies that must be possessed by students after carrying out learning through the use of teaching materials. After the core competencies and indicators, then proceed with the presentation of the material, the picture is as follows:

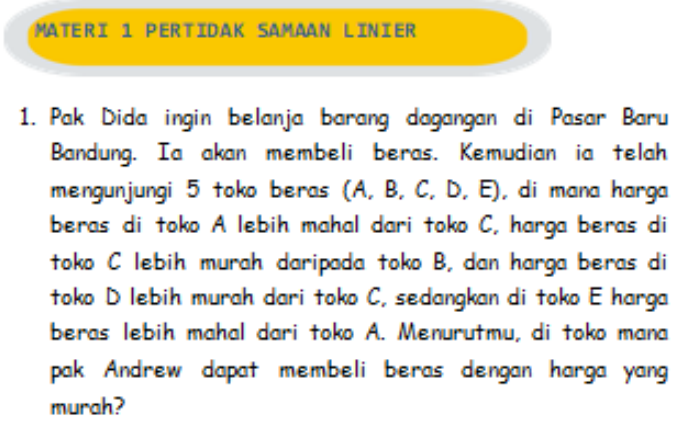

1. Pak Dida ingin belanja barang dagangan di Pasar Baru Bandung. Ia akan membeli beras. Kemudian ia telah mengunjungi 5 toko beras $(A, B, C, D, E)$, di mana harga beras di toko $A$ lebih mahal dari toko $C$, harga beras di toko $C$ lebih murah daripada toko $B$, dan harga beras di toko $D$ lebih murah dari toko $C$, sedangkan di toko $E$ hargo beras lebih mahal dari toko $A$. Menurutmu, di toko mana pak Andrew dapat membeli beras dengan harga yang murah?

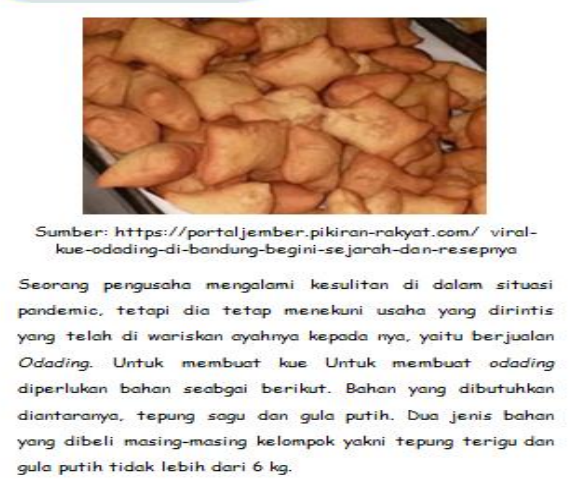

Figure 5 Presentation of Material Based on Problems

The material presented in this teaching material is made by giving problems at the beginning of learning. Problems at the beginning of the lesson were made by providing those that were related to everyday life, for example, students were given food processing problems that had to make the food with available ingredients so that maximum benefits were obtained. Such problems are made so that students better understand the usefulness of linear programming material in everyday life. In the delivery of the material, an understanding of the entrepreneurial spirit is also given which is an integral part of this material, such as the following examples: 


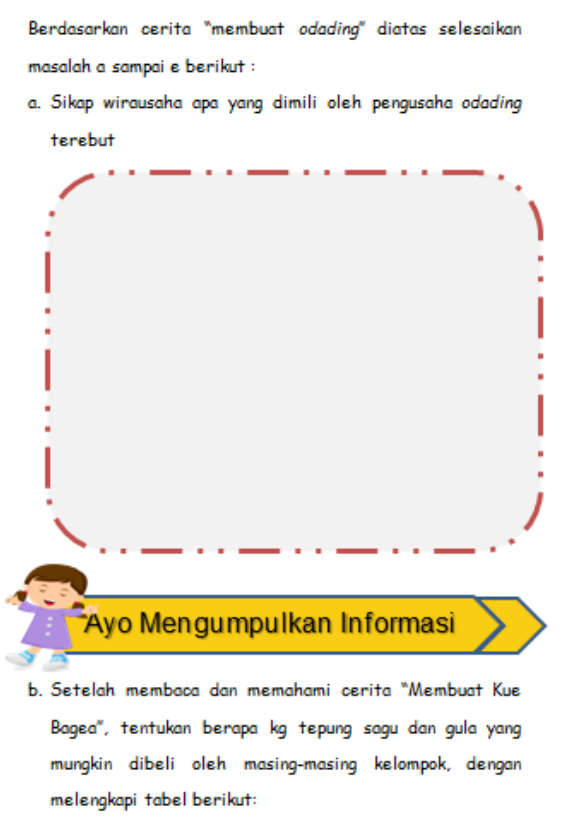

Figure. 6 Giving Entrepreneurship in the Context of Problems in Linear Program Material

One of the things taken is a business problem that is experiencing problems in the midst of a pandemic situation; the question is directed to what the entrepreneurial attitude is in the illustration of the problem. The answers from students will reflect the attitude of students in responding to problems in the business world, which is certainly in this pandemic situation they are required to think creatively so that they are able to create other businesses that can survive the many bankruptcies experienced by various entrepreneurs. Through this question, it is hoped that vocational students who use this teaching material will understand well the spirit of entrepreneurship that exists in the context of everyday life. The last part of this teaching material is an exercise and a summary, as shown in the image below:

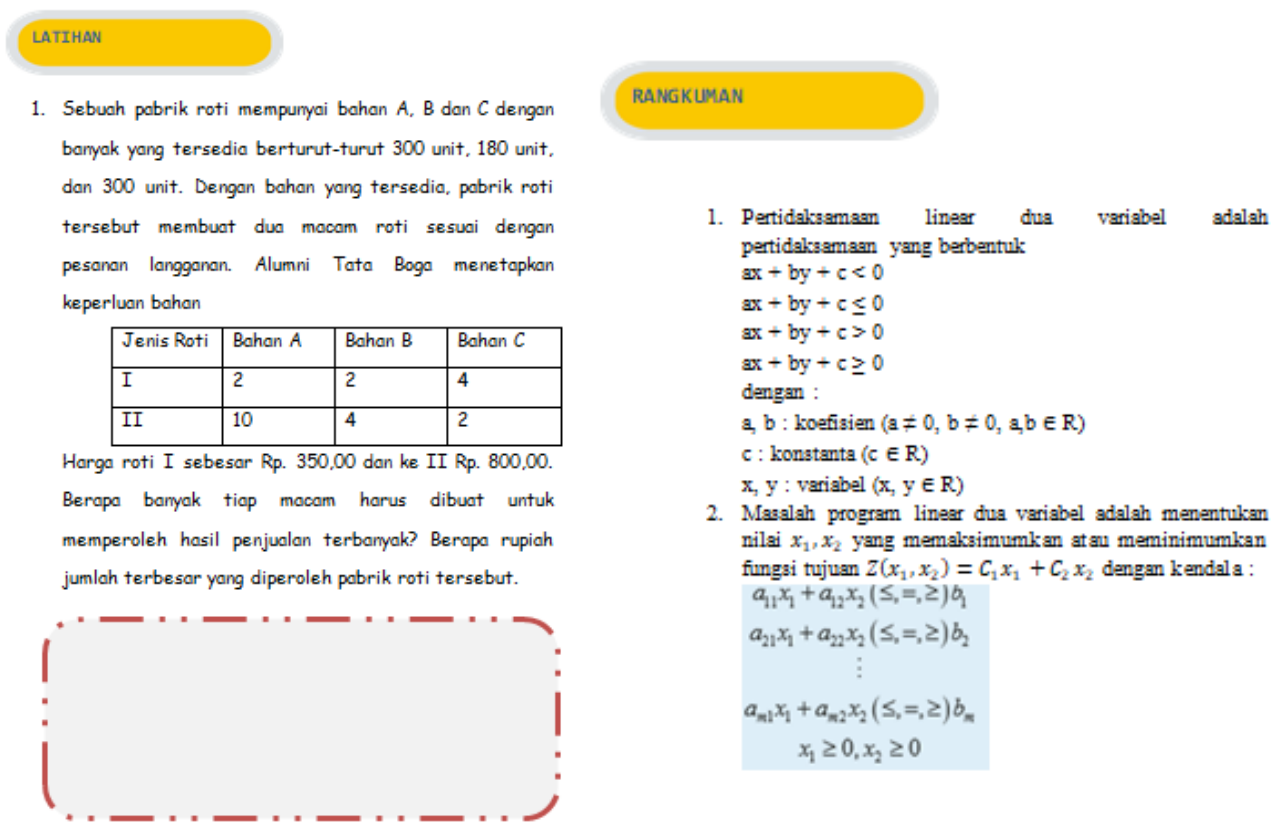

Figure 7 Exercises and Summary in Teaching Materials

The exercises in this teaching material are made with the problems that exist in everyday life. This is important as part of the reflection after studying this teaching material. The exercises are made with the aim that students really understand the material about linear 
programming, and then the exercises are also to introduce students to the problems in the business world that will be encountered when they have graduated from SMK units whose orientation is the industrial world and the business world.

The third stage is the development stage. The development stage is the core stage before this teaching material is used in the form of implementation in the classroom. Several validations were carried out in order to strengthen the teaching materials made by the teacher. Several experts were invited to be able to assess the teaching materials prepared by the research team. The first validation was regarding the media, the media in terms of the appearance contained in this teaching material. Media validation was carried out by Mr. Sandi M.Sc. as a lecturer in the informatics study program and also as a multimedia teacher at SMK Rosma. The results of the Media Validation are as follows:

Table 1 Validation Results of Media Experts

\begin{tabular}{|c|c|c|c|}
\hline $\begin{array}{l}\text { Assessment } \\
\text { Aspects }\end{array}$ & Question & Validator 1 & Validator 2 \\
\hline \multirow[t]{2}{*}{ Size } & $\begin{array}{l}\text { Compliance with ISO standard } \\
\text { module size }\end{array}$ & 3 & 3 \\
\hline & $\begin{array}{l}\text { Suitability of module size with } \\
\text { module content }\end{array}$ & 3 & 4 \\
\hline \multirow[t]{6}{*}{$\begin{array}{l}\text { Cover } \\
\text { Design }\end{array}$} & $\begin{array}{l}\text { Suitability of module size with } \\
\text { module content }\end{array}$ & 3 & 3 \\
\hline & Showing a good center point & 3 & 3 \\
\hline & $\begin{array}{l}\text { The size of the module title } \\
\text { font is more dominant and } \\
\text { proportional to the size of the } \\
\text { module, the author's name }\end{array}$ & 3 & 3 \\
\hline & $\begin{array}{l}\text { The module title color } \\
\text { contrasts with the background } \\
\text { color }\end{array}$ & 4 & 3 \\
\hline & $\begin{array}{l}\text { Do not use too many font } \\
\text { combinations }\end{array}$ & 3 & 4 \\
\hline & $\begin{array}{l}\text { The skin illustration of } \\
\text { teaching materials describes } \\
\text { the content / teaching material } \\
\text { and reveals the character of the } \\
\text { object }\end{array}$ & 3 & 3 \\
\hline \multirow{7}{*}{$\begin{array}{l}\text { Content } \\
\text { Design of } \\
\text { Teaching } \\
\text { Materials } \\
\end{array}$} & $\begin{array}{l}\text { The consistency of the } \\
\text { placement of layout elements }\end{array}$ & 3 & 3 \\
\hline & Harmony of layout elements & 3 & 3 \\
\hline & Don't use too many fonts & 3 & 3 \\
\hline & $\begin{array}{l}\text { The use of font variations } \\
\text { (bold, italic, all caption, small } \\
\text { caption) is not excessive }\end{array}$ & 4 & 3 \\
\hline & $\begin{array}{l}\text { Spacing between lines of } \\
\text { normal text arrangement }\end{array}$ & 3 & 3 \\
\hline & $\begin{array}{l}\text { The topography of the module } \\
\text { content makes it easy to } \\
\text { understand }\end{array}$ & 3 & 3 \\
\hline & Clarity and functionality of & 4 & 4 \\
\hline
\end{tabular}




\begin{tabular}{llll}
\hline $\begin{array}{l}\text { Assessment } \\
\text { Aspects }\end{array}$ & Question & Validator 1 & Validator 2 \\
\hline & images with concept & & \\
\hline $\begin{array}{l}\text { Comparison of text and image } \\
\text { sizes }\end{array}$ & 4 & 3 \\
\hline Interesting module appearance & 3 & 55 \\
\hline total & 55 & \\
\hline Total number & 110 & \\
\hline Percentage & 80.88 & \\
\hline
\end{tabular}

Information; 4 = very good, 3 = good, 2 = poor, 1 = very poor

The results of the media validation also illustrate that the module size is in accordance with UNESCO standards, namely $15.5 \times 23 \mathrm{~cm}$. The use of letters is also good, in terms of size and type, so that it is easy for students to read. Images are made clearly and include the source of the image, so that the image does not violate the copyright of the creator. Comparison of text and images as well as validate have evaluated it well in the sense that the composition has met the standard criteria, meaning that the image is neither too big nor too small. Results of media validation others suggests that the overall media displayed is well and able to give the development of student abilities in math and orientation to the world. This is evidenced from several notes that the use of the design for the content is good but needs improvement in the cover so that the appearance of this teaching material can be more attractive to students, so the validate suggests revising the cover design that has been made by the research team. The results and notes from the revision of validate are made as follows:

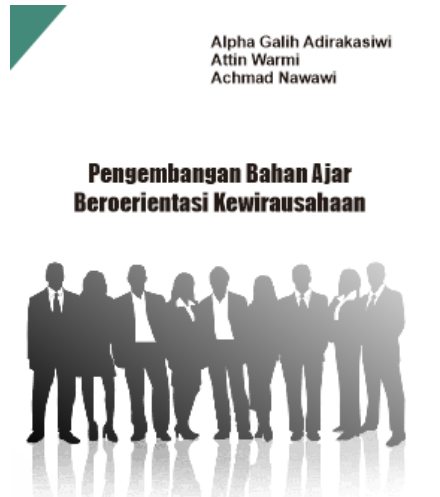

Before the Revision

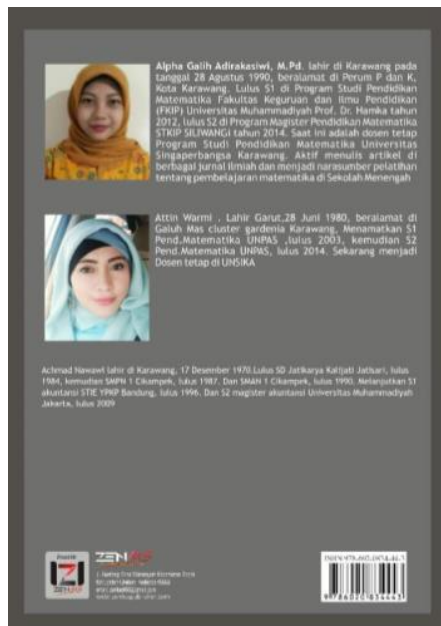

After the Revision

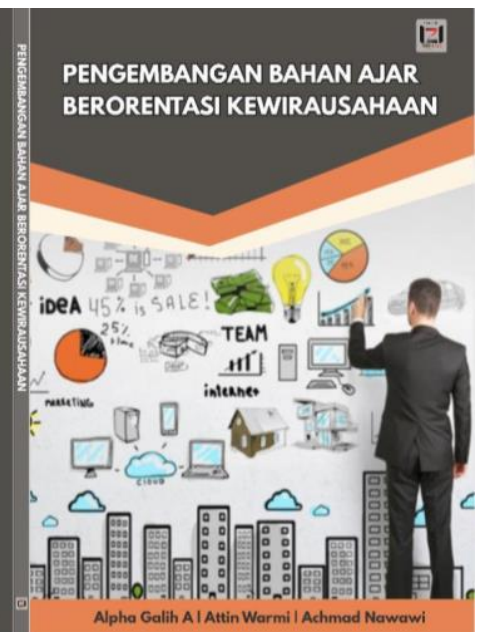

Figure 8 Revised Cover Design for Teaching Materials

The discussion is carried out by an expert validated who is an expert in graphic design, after a revision is then consulted with validate. The image on the right is a revised image of the cover design of teaching materials made. The validated appreciates the performance of the research team who revised the cover and gave appreciation because the cover made was in accordance with the direction of the validated; the back page also includes the author's profile so that students understand about the research team that made this teaching material. After being given to the media expert validator, the validator considers it sufficient for the media displayed in this teaching material. Then the second validator is given to the linguist. The appointed linguist, namely Dr. Agus Rofi'I, who is a language and teacher of Indonesian language from SMK Rosma. The results of the language validate are as follows: 
Table 2 Results of Linguist Validation

\begin{tabular}{|c|c|c|c|}
\hline $\begin{array}{l}\text { Assessment } \\
\text { Aspects }\end{array}$ & Question & $\begin{array}{l}\text { Validator } \\
1\end{array}$ & $\begin{array}{l}\text { Validator } \\
2\end{array}$ \\
\hline \multirow[t]{13}{*}{$\begin{array}{l}\text { Readability } \\
\text { Aspects }\end{array}$} & $\begin{array}{l}\text { Using good and correct language } \\
\text { rules }\end{array}$ & 3 & 4 \\
\hline & $\begin{array}{l}\text { Using terms that are in } \\
\text { accordance with the concepts on } \\
\text { the subject }\end{array}$ & 4 & 3 \\
\hline & $\begin{array}{l}\text { The language used is } \\
\text { straightforward and easy for } \\
\text { students to understand. }\end{array}$ & 3 & 3 \\
\hline & $\begin{array}{l}\text { The language used is } \\
\text { communicative. }\end{array}$ & 3 & 4 \\
\hline & $\begin{array}{l}\text { The accuracy of language } \\
\text { selection in describing the } \\
\text { material }\end{array}$ & 3 & 3 \\
\hline & $\begin{array}{l}\text { The sentence used represents the } \\
\text { content of the message or } \\
\text { information to be conveyed }\end{array}$ & 3 & 3 \\
\hline & $\begin{array}{l}\text { The sentences used are simple } \\
\text { and direct to the point. }\end{array}$ & 3 & 3 \\
\hline & Spelling accuracy & 3 & 3 \\
\hline & Consistent use of terms & 3 & 3 \\
\hline & $\begin{array}{l}\text { Consistent use of symbols or } \\
\text { icons }\end{array}$ & 4 & 4 \\
\hline & total & 35 & 36 \\
\hline & Total number & 65 & \\
\hline & Percentage & 81.25 & \\
\hline
\end{tabular}

Information; $4=$ very good, $3=$ good, $2=$ poor, $1=$ very poor

The results of the language validated have provided an overview that the teaching materials are good enough and use language that uses standard language, then from the second validated who is a language teacher at SMK Rosma also gives an assessment that the language used is suitable for use in mathematics learning at SMK, in addition to the language used easy to understand as well as the use of terms that are widely used in everyday life, however, there are some notes from the language validated, the notes are as follows;

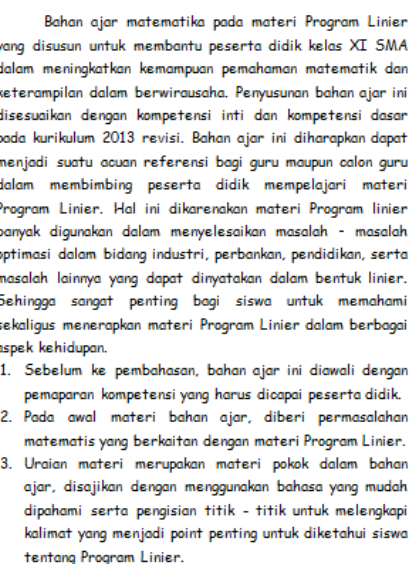

Before the Revision

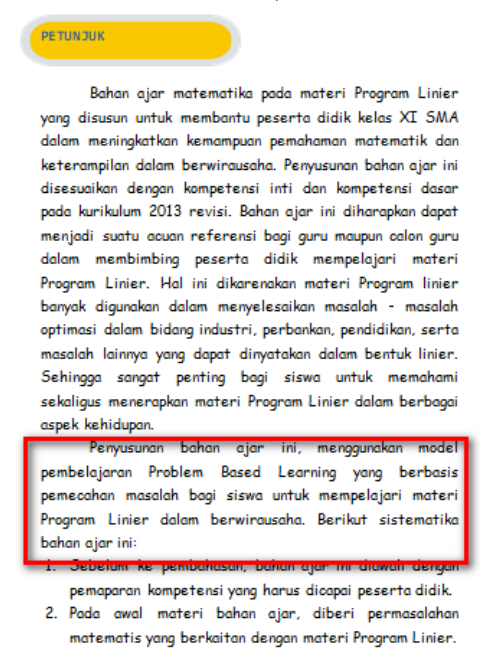

After the Revision

Figure 9 Revision of Language Usage 
In the section of the validation's instructions, there are suggestions that this teaching material should be directed to the development of what model, and the research team agreed that the development of the model used a problem-based learning model. This is because this model provides students the opportunity to construct mathematical concepts through everyday problems that can be used as a starting point for students to understand the linear program material. The use of language in general already fulfills good language rules so there is no need for much revision and researchers can continue to the implementation stage after this development activity. Then the last validator is about material experts. The first expert validator is Kintoko, M.Pd., who is a mathematics education lecturer and is currently taking a doctorate by taking the theme of telling stories in mathematics so that we consider it appropriate to be a validator in this teaching material, in addition to Mr. Kintoko, the second material validator is mathematics teacher at SMK Rosma Karawang. The results of the material expert validator are as follows:

Table 3 Results of Material Expert Validation

\begin{tabular}{|c|c|c|c|}
\hline $\begin{array}{l}\text { Assessment } \\
\text { Aspects }\end{array}$ & Question & Validator 1 & Validator 2 \\
\hline \multirow[t]{4}{*}{$\begin{array}{l}\text { Didactic } \\
\text { Aspects }\end{array}$} & $\begin{array}{l}\text { Inviting students to be active in the } \\
\text { learning process }\end{array}$ & 4 & 4 \\
\hline & $\begin{array}{l}\text { Emphasizes the process of finding } \\
\text { concepts }\end{array}$ & 3 & 3 \\
\hline & $\begin{array}{l}\text { Has a variety of stimuli through } \\
\text { various media and student activities. }\end{array}$ & 3 & 3 \\
\hline & $\begin{array}{l}\text { Develop social and emotional } \\
\text { communication skills. }\end{array}$ & 3 & 3 \\
\hline \multirow[t]{5}{*}{$\begin{array}{l}\text { Construction } \\
\text { Aspects }\end{array}$} & $\begin{array}{l}\text { Use language appropriate to the } \\
\text { child's maturity level }\end{array}$ & 4 & 4 \\
\hline & $\begin{array}{l}\text { The suitability of the questions used } \\
\text { with the student's ability level }\end{array}$ & 3 & 4 \\
\hline & $\begin{array}{l}\text { The sentences used are easy to } \\
\text { understand, and do not cause } \\
\text { multiple meanings. }\end{array}$ & 3 & 3 \\
\hline & Use of communicative language & 3 & 4 \\
\hline & Complete identity & 3 & 3 \\
\hline \multirow[t]{2}{*}{$\begin{array}{l}\text { Technical } \\
\text { Aspects }\end{array}$} & $\begin{array}{l}\text { Clarity of writing / images / graphics } \\
\text { / illustrations }\end{array}$ & 4 & 4 \\
\hline & $\begin{array}{l}\text { The physical appearance of the book } \\
\text { can encourage students' interest in } \\
\text { reading }\end{array}$ & 2 & 3 \\
\hline \multirow[t]{7}{*}{$\begin{array}{l}\text { Material } \\
\text { Quality }\end{array}$} & Completeness of the material & 4 & 3 \\
\hline & $\begin{array}{l}\text { Suitability of indicators with Basic } \\
\text { Competencies }\end{array}$ & 4 & 4 \\
\hline & $\begin{array}{l}\text { Suitability of the material with } \\
\text { learning objectives }\end{array}$ & 3 & 3 \\
\hline & $\begin{array}{l}\text { The correctness of the concept / } \\
\text { material }\end{array}$ & 3 & 3 \\
\hline & $\begin{array}{l}\text { Accuracy of drawings, diagrams and } \\
\text { illustrations }\end{array}$ & 4 & 3 \\
\hline & Accuracy of notations and symbols & 3 & 3 \\
\hline & Systematic order of matter & 3 & 4 \\
\hline
\end{tabular}




\begin{tabular}{llll}
\hline $\begin{array}{l}\text { Assessment } \\
\text { Aspects }\end{array}$ & Question & Validator 1 & Validator 2 \\
\hline & Train students to think creatively & 4 & 3 \\
\hline & total & 63 & 64 \\
\hline Total number & 127 & \\
\hline Percentage & $83.46 \%$ & \\
\hline
\end{tabular}

The material expert gives an idea that the material has been well designed. The problems raised also meet the criteria for students to carry out investigations in learning that can be done in groups. Then the teaching materials can facilitate to apply the given concepts such as finding the concept of linear inequality using constructivism so that students can find their own concepts. The validator has also assessed the suitability of the material being taught with indicators and learning objectives, then the use of notations and symbols has also been very good. Some notes from the material expert validator are as follows:

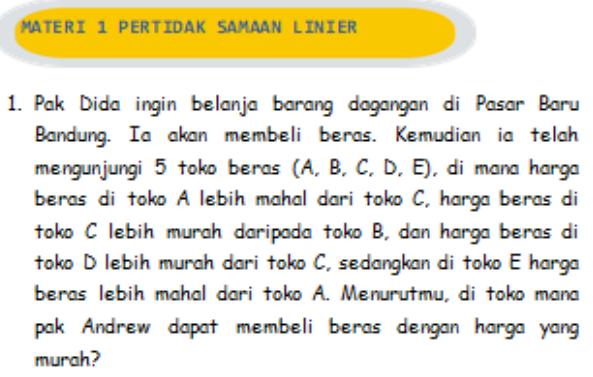

1. Pak Dida ingin belanja barang dagangan di Pasar Baru Bandung. Ia akan membeli beras. Kemudian ia telah mengunjungi 5 toko beras ( $A, B, C, D, E$ ), di mana harga beras di toko $A$ lebih mahal dari toko $C$, harga beras di toko $C$ lebih murah daripada toko $B$, dan harga beras di toko $D$ lebih murah dari toko $C$, sedangkan di toko $E$ harga beras lebih mahal dari toko $A$. Menurutmu, di toko mana pak Andrew dapat membeli beras dengan harga yang murah?

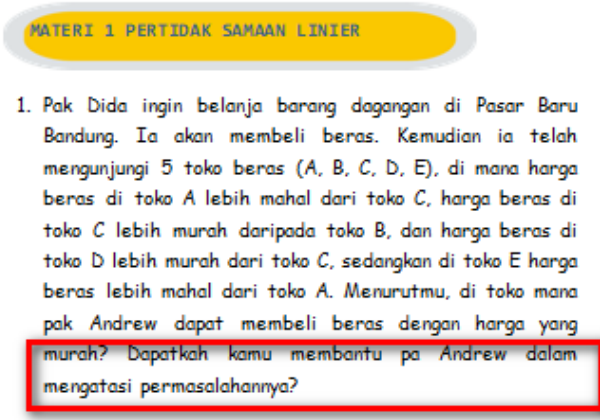

After the Revision
Before the Revision

d. Berapa baryak pangkat tertinggi dari variabel-variabel pada pertidaksamoan yang Anda peroleh pada jawaban masalah $1 \mathrm{~b}$
A1

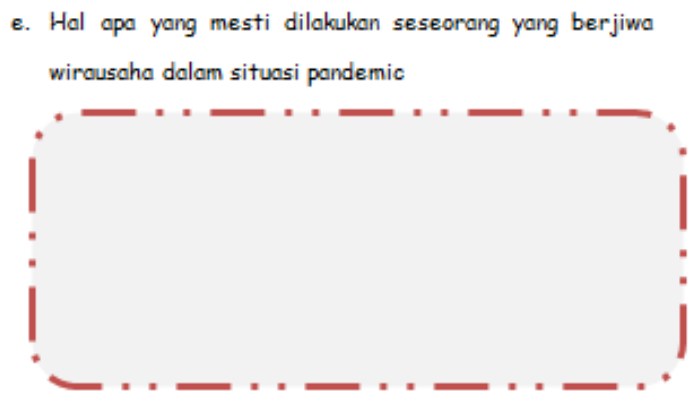

A2

Figure 10 Revisions of Material Validators

A1 is a revision of the follow-up questions so that students can understand them well. Additional other well so that the entrepreneurial spirit can be well understood from the situation that a given problem. Then for A2 it focuses more on the entrepreneurial spirit that students can develop after learning mathematics using the teaching materials that have been made. Overall the material has been made effectively and efficiently without eliminating the material to be studied; entrepreneurial elements also appear in the problems given at the beginning of the lesson.

The fourth stage of developing this teaching material is implementation. Implementation is done in small groups and large groups. In implementation, it is also used to see the 
effectiveness and attractiveness of students in using teaching materials. The first stage of implementation is used in small groups with a total of 20 students. The learning process is carried out online because of the Covid-19 pandemic situation. Measurement in small groups is also to see the mathematical literacy of vocational students after using the teaching materials made. All students are given teaching materials that have been validated by the validator. The results of the attractiveness analysis got a percentage of $79 \%$ with attractive criteria. This shows that the teaching materials made meet the elements of student attractiveness. Two students were interviewed, namely S1 and S2 about what was interesting about this teaching material. S1 (1st student) gave a response that I became interested because the problems given at the beginning of the lesson made me understand the meaning of mathematics in the business world, especially I am a vocational student whose orientation is the world of work and the world of business. I like math material if it is packaged in that way, then S2 (2nd Student) gave the response that if mathematics was packaged like this it would make us know the benefits of mathematics in everyday life, I am also very happy with the insertion of an entrepreneurial spirit that makes me more understand the traits an entrepreneur must have so that it can be a provision for me when I enter the business world.

Then for practicality results obtained a percentage of $81 \%$ with good criteria. Several students were interviewed about the practicality of the teaching materials used in mathematics learning. Doctoral students gave a response that I became interested in mathematics through this teaching material and then this teaching material is practical and effective to use because the content is very simple but easy to understand. This shows that the results of the practicality and attractiveness of students can be used as the basis for implementing large groups, some notes that still need improvement of course in terms of the presentation of teaching materials so that students first understand the instructions and competencies that must be achieved in understanding this mathematics material.

Based on the results of student attractiveness and student practicality in teaching materials, then the application is carried out in large groups. Large groups were taken as many as 4 classes from different skill groups, namely multimedia and computer network techniques for students in class XI SMK, then also applied at SMKN 1 Karawang as many as 4 classes also to be able to provide an overview of the effectiveness of the teaching materials made by the research team . This stage is given in order to provide whether mathematical literacy and an entrepreneurial spirit can be improved through the use of teaching materials. The results of the data analysis conducted by the research team on mathematical literacy showed that students were able to improve mathematical literacy after using teaching materials designed by the teacher. The pretest average score obtained by students from the 8 classes tested was 67 while the post-test average score given to the 8 classes was 85 . The results of the data analysis test using the paired sample t test obtained a significance value of 0,0001 , thus that the material effective teaching in improving mathematical literacy of vocational school students in Karawang. To see an entrepreneurial spirit, several entrepreneurial attitudes were chosen, namely not easily giving up, thinking original and innovative, and having high motivation, based on the results given through a questionnaire that students experience a good understanding of the entrepreneurial spirit that students must have. One of the doctoral students commented that with this teaching material I could imagine that the challenges of an entrepreneurial person could be used as initial capital for me to build a business later, in line with S3; S4 commented that I became more aware of the nature of entrepreneurship, especially in overcoming times. - Difficult times like now, namely in a pandemic situation, how do we provide innovation when marketing the products we will sell if we become entrepreneurs.

The last stage is evaluation. Evaluation is used to make improvements to the teaching materials made so that they can be disseminated especially in the Karawang area. Evaluation is also carried out with a validated how to respond to the responses to the results obtained at the 
implementation stage, in general, that the teaching materials have met the feasibility and can be distributed to schools in SMK Karawang. Then this teaching material has been published and has received the International Standard Book Number (ISBN) from publishers in the West Java region.

\section{Discussion}

The results of this study are focused on developing mathematics teaching materials with entrepreneurial orientation. The development of teaching materials uses the ADDIE model. The teaching materials developed have gone through development stages starting from analysis, design, development, implementation and evaluation. The analysis phase was based on the analysis of the needs of the students who were the target in the study, namely vocational students. The analysis is based on the need for mathematical literacy and entrepreneurial spirit. Mathematical literacy is a very hot issue, especially the value of mathematical literacy results based on PISA in 2018 which is still under ASEAN countries, especially Thailand and Singapore. Therefore it is necessary to learn, especially the preparation of teaching materials that can facilitate students to be able to increase students' mathematical literacy. The development of teaching materials made by the research team facilitates non-routine questions which are part of problem solving that characterizes the questions that measure mathematical literacy skills.

The teaching materials developed are able to improve mathematical literacy because the teaching materials are developed in accordance with the problems that occur in students and are daily problems encountered by students. The problems of the business world are also interesting things that are displayed in teaching materials (Genc \& Erbas, 2020; Umbara \& Suryadi, 2019). Problems relating to the business world are in line with vocational students who are oriented towards industry and business (Nurjamiah et al., Nd) (Zhang, 2019) (Belcher $\&$ others, 2020). Giving problems at the beginning of learning on this teaching material is intended to facilitate and introduce students to the entrepreneurial nature and spirit that students must have. Entrepreneurial traits must be instilled in students so that they are familiar with the habits of an entrepreneur who is always faced with competition and innovation in every era. The results of this study indicate that students understand well the entrepreneurial traits that an entrepreneur must have if later they will become entrepreneurs after graduating from SMK. The results of this study are in line with the results of research (Haara, 2018) which concludes that entrepreneurial oriented learning can improve students' entrepreneurial spirit. Another thing that is interesting from this research is the validated gives the same conclusion that this teaching material after obtaining an ISBN number is suitable to be distributed and can be used by mathematics teachers for the development of literacy and entrepreneurial spirit of students, especially vocational students.

\section{Conclusions}

Based on the results of data analysis and processing that have been carried out in this study, the development of teaching materials using the ADDIE model has met the appropriate and valid criteria by media, language and media expert validates. Another result of developing this teaching material besides meeting the eligibility criteria is that the teaching materials developed are able to increase mathematical literacy and instill entrepreneurial spirit for students. 


\section{Acknowledgements:}

Thanks are shown to the rector of the Singaperbangsa Karawang University who facilitated the research implementation and also provided funds for the research implementation until the completion of this research. To all those who have helped this research, I would like to thank, especially the six validates of the development of this teaching material.

\section{References}

Amir, M. F., Mufarikhah, I. A., Wahyuni, A., Nasrun, N., \& Rudyanto, H. E. (2019). Developing 'Fort Defending'Game as a Learning Design for Mathematical Literacy Integrated to Primary School Curriculum in Indonesia. Elementary Education Online, 18(3).

Asmara, A. S., Waluya, S. B., \& Rochmad, R. (2017). Analysis of Mathematics Literacy Based on Mathematical Ability. Scholaria: Jurnal Pendidikan Dan Kebudayaan, 7(2), 135-142.

Belcher, M. J., \& others. (2020). Examining Middle Graders' Experiences with a STEM Entrepreneurial-Based Curriculum and its Impact on Mathematics Learning: A Design Study.

Diputra, K. K. S., Diputra, K. S., Suarjana, I. M., \& Japa, I. G. N. (2019). Investigating The Mathematical Literacy of Primary School Students in Curriculum 2013. 5th International Conference on Education and Technology (ICET 2019).

Ekawati, R., Susanti, S., \& Chen, J.-C. (2020). PRIMARY STUDENTS'MATHEMATICAL LITERACY: A CASE STUDY. Infinity Journal, 9(1), 49-58.

Fajriyah, E., Mulyono, M., \& Asikin, M. (2019). Mathematical Literacy Ability Reviewed from Cognitive Style of Students on Double Loop Problem Solving Model with RME Approach. Unnes Journal of Mathematics Education Research, 8(1), 57-64.

Frederiksen, S. H. (2017). Learning to become entrepreneur (ial). New perspectives on enterprise education in practice. $\mathrm{PhD}$ thesis, Aarhus University.

Gabriel, F., Buckley, S., \& Barthakur, A. (2020). The impact of mathematics anxiety on self-regulated learning and mathematical literacy. Australian Journal of Education, 64(3), 227-242.

Genc, M., \& Erbas, A. K. (2020). Exploring Secondary Mathematics Teachers' Conceptions of the Barriers to Mathematical Literacy Development. International Journal for Mathematics Teaching and Learning, 21(2), $143-173$.

Ghani, M. T. A., Malim, T., \& Daud, W. (2018). Adaptation of ADDIE instructional model in developing educational website for language learning. Global Journal Al-Thaqafah, 8 (2), 7, 16.

Gusmida, R., Islami, N., \& others. (2017). The development of learning media for the kinetic theory of gases using the ADDIE model with augmented reality. Journal of Educational Sciences, 1(1), 1-10.

Haara, F. O. (2018). Pedagogical entrepreneurship in school mathematics: an approach for students' development of mathematical literacy. International Journal for Mathematics Teaching and Learning, 19(2), 253-268.

Hägg, G., \& Kurczewska, A. (2019). Who is the student entrepreneur? Understanding the emergent adult through the pedagogy and andragogy interplay. Journal of Small Business Management, 57(sup1), 130-147.

Hasan, M., Hatidja, S., Nurjanna, G., FA, G., \& Ma'ruf, M. I. (2019). Entrepreneurship learning, positive psychological capital and entrepreneur competence of students: a research study. Entrepreneurship and Sustainability Issues, 7(1), 425-437.

Hayati, T. R., \& Kamid, K. (2019). Analysis of Mathematical Literacy Processes in High School Students. International Journal of Trends in Mathematics Education Research, 2(3), 116-119.

Ic, U., \& Tutak, T. (2018). Correlation between Computer and Mathematical Literacy Levels of 6th Grade Students. European Journal of Educational Research, 7(1), 63-70.

ILHAN, A., \& ASLANER, R. (2017). Investigation of the Effects of the Use of Dynamic Geometry Software on the Teaching of Geometry Subjects to Visual Mathematics Literacy Perception Levels of Elementary Mathematics Teacher Candidates. Necatibey Faculty of Education Electronic Journal of Science \& Mathematics Education, 11(2).

Kamid, Marzal, J., Heriyanti, Asyhar, R., \& Sutrisno. (2020). Responding the integrated model of entrepreneur characteristic with STEM to enhance students creativity. AIP Conference Proceedings, 2215(1), 20010. 
Kang, H., \& Cogan, L. (2020). The Differential Role of Socioeconomic Status in the Relationship between Curriculum-Based Mathematics and Mathematics Literacy: the Link Between TIMSS and PISA. International Journal of Science and Mathematics Education, 1-16.

Kastberg, D., Chan, J. Y., \& Murray, G. (2016). Performance of US 15-Year-Old Students in Science, Reading, and Mathematics Literacy in an International Context: First Look at PISA 2015. NCES 2017-048. National Center for Education Statistics.

Kelana, J. B., Wardani, D. S., Firdaus, A. R., Altaftazani, D. H., \& Rahayu, G. D. S. (2020). The effect of STEM approach on the mathematics literacy ability of elementary school teacher education students. Journal of Physics: Conference Series, 1657(1), 12006.

Kitsantas, A., Cleary, T. J., Whitehead, A., \& Cheema, J. (2020). Relations among classroom context, student motivation, and mathematics literacy: a social cognitive perspective. Metacognition and Learning, 1-19.

Leonard, J., Walker, E. N., Bloom, V. R., \& Joseph, N. M. (2020). Mathematics Literacy, Identity Resilience, and Opportunity Sixty Years Since Brown v. Board. Journal of Urban Mathematics Education, 13(1B), $12-37$.

Letwinsky, K. M. (2017). Examining the Relationship between Secondary Mathematics Teachers' Self-Efficacy, Attitudes, and Use of Technology to Support Communication and Mathematics Literacy. International Journal of Research in Education and Science, 3(1), 56-66.

Mariani, S., Hendikawati, P., \& others. (2017). Mathematizing process of junior high school students to improve mathematics literacy refers PISA on RCP learning. Journal of Physics Conference Series, 824(1), 12049.

Nurhidayati, N., Sumarno, S., \& Kartikowati, S. (n.d.). The Effect of Pedagogic Competency and Family Environment Towards Students Entrepreneur Character in Madrasah Aliyah Negeri (MAN) 1 Pekanbaru. INTERNATIONAL JOURNAL OF ECONOMIC, BUSINESS AND APPLICATIONS, 3(1).

Nurjamiah, N., Sumarno, S., \& Gimin, G. (n.d.). Development of E-Millenial Entrepreneur Learning Model for Entrepreneurs Learning of Vocational School. Journal of Educational Sciences, 4(3), 657-667.

Obrecht, J.-J. (2016). Sustainable entrepreneurship education: a new field for research in step with the'effectual entrepreneur'. International Journal of Entrepreneurship and Small Business, 29(1), 83-102.

Pradana, L., Sholikhah, O., Maharani, S., \& Kholid, M. (2020). Virtual mathematics kits (VMK): Connecting digital media to mathematical literacy. International Journal of Emerging Technologies in Learning (IJET), 15(3), 234-241.

Pujiastuti, H., Haryadi, R., \& Ridwan, F. (2020). DEVELOPMENT OF MATHEMATICS TEACHING MATERIALS BASED ON SCIENTIFIC APPROACH FOR MATHEMATICS LEARNING. AKSIOMA: Jurnal Program Studi Pendidikan Matematika, 9(3), 591-600.

Purpura, D. J., Schmitt, S. A., \& Ganley, C. M. (2017). Foundations of mathematics and literacy: The role of executive functioning components. Journal of Experimental Child Psychology, 153, 15-34.

Rahmi, E. (2017). Intention Entrepreneur Of The Students And Its Relationship With The Learning Quality. International Conference on Global Education V, 2.

Rusdi, R., Fauzan, A., Arnawa, I. M., \& Lufri, L. (2019). Development of Mathematics Teaching Materials Based on Realistic Mathematics Education and Literacy in Junior High School. 1st International Conference on Innovation in Education (ICoIE 2018).

Sumirattana, S., Makanong, A., \& Thipkong, S. (2017). Using realistic mathematics education and the DAPIC problem-solving process to enhance secondary school students' mathematical literacy. Kasetsart Journal of Social Sciences, 38(3), 307-315.

Ülger, T. K., Bozkurt, I., \& Altun, M. (2020). Thematic Analysis of Articles Focusing on Mathematical Literacy in Mathematics Teaching-Learning Process. Education \& Science/Egitim ve Bilim, 45(201).

Umbara, U., \& Suryadi, D. (2019). Re-Interpretation of Mathematical Literacy Based on the Teacher's Perspective. International Journal of Instruction, 12(4), 789-806.

Yüca, G. (2017). THE EVALUATION OF MATHEMATICS LITERACY IN TURKEY BASED ON THE 2015 PISA RESULTS FROM THE PERSPECTIVE OF MATHEMATICS TEACHER CANDIDATES'OPINIONS AND RECOMMENDATIONS FOR SOLUTIONS. European Journal of Education Studies.

Yuliati, U., Hartini, R., Waluyo, D. E., \& Triningsih, S. (2016). STUDENTS ENTREPRENEUR MODEL IN PRIVATE UNIVERSITY. Research Report, 546-560. 
Zhang, H. (2019). Elementary Exploration on the Reform of Mathematics Teaching in Higher Vocational and Technical Education with Chinese Characteristics. 2019 International Conference on Management, Education Technology and Economics (ICMETE 2019). 